\title{
ANALISIS PENGARUH KUALITAS PRODUK, KUALITAS PELAYANAN, HARGA, DAN LOKASI TERHADAP KEPUTUSAN PEMBELIAN PADA WARUNG-WARUNG PECEL DI BLITAR
}

\author{
Fitria Ika Agustina \\ ASM Mataram \\ beautyanakku@gmail.com
}

\begin{abstract}
ABSTRAK - Perkembangan bisnis makanan di kota Blitar semakin lama semakin meningkat, menyebabkan semua pengelola bisnis makanan harus berusaha lebih baik supaya bertahan dalam menghadapi persaingan bisnis yang ada .Tujuan dilakukan penelitian ini adalah untuk menganalisis pengaruh Kualitas Produk, Kualitas Pelayanan, Harga dan Lokasi baik secara parsial maupun simultan terhadap Keputusan Pembelian pada Warung-Warung Pecel di Blitar. Penelitian ini menggunakan pendekatan kuantitatif dengan jenis penelitian asosiatif. Teknik pengambilan sampel yang digunakan dalam penelitian ini adalah pruposive sampling sebanyak 100 orang responden (konsumen). Alat pengumpulan data menggunakan kuesioner. Data yang terkumpul dari responden di analisis menggunakan analisis regresi linier berganda. Hasil penelitian menunjukkan bahwa kualitas produk, kualitas pelayanan, harga dan lokasi berpengaruh secara simultan dan parsial terhadap Keputusan Pembelian pada Warung-Warung Pece/ di Blitar dan Kualitas Produk merupakan variabel yang paling dominan terhadap Keputusan Pembelian pada Warung-Warung Pecel di Blitar. Bagi para pengelola warung-warung pecel di Blitar, sebaiknya meningkatkan kualitas produk yang ditawarkan, sehingga dapat meningkatkan keputusan pembelian.
\end{abstract}

Kata Kunci : Kualitas Produk, Kualitas Pelayanan, Harga, Lokasi, Keputusan Pembelian

\section{PENDAHULUAN}

Perkembangan teknologi dan industri membawa dampak bagi kehidupan manusia terutama pada dunia usaha saat ini. Di samping itu, banyaknya usaha bermunculan baik perusahaan kecil maupun besar berdampak pada persaingan yang ketat antar perusahaan, terutama persaingan yang berasal dari perusahaan sejenis. Hal ini menyebabkan perusahaan yang menerapkan konsep pemasaran perlu mencermati perilaku konsumen dan faktor-faktor yang mempengaruhi keputusan pembeliannya dalam usaha-usaha pemasaran sebuah produk yang dilakukan. Hal tersebut dikarenakan dalam konsep pemasaran, salah satu cara untuk mencapai tujuan perusahaan adalah dengan mengetahui apa kebutuhan dan keinginan konsumen atau pasar sasaran serta memberikan kepuasan yang diharapkan secara lebih efektif dan efisien dibandingkan para pesaing (Kotler, 2002).

Salah satu persaingan yang cukup ketat saat ini adalah persaingan pada bisnis kuliner. Padatnya aktivitas di zaman modern dewasa ini menyebabkan kebanyakan orang tidak mempunyai banyak waktu luang untuk mempersiapkan sendiri makanan di rumah dan cenderung ingin menikmati makanan yang siap saji. Bisnis ini cukup menjanjikan karena kebutuhan utama yang harus dipenuhi orang yang tidak bisa diingkari adalah makanan.
Makanan adalah kebutuhan pokok setiap insan manusia. Dalam teori Hierarki Kebutuhan Maslow menyebutkan bahwa makanan merupakan salah satu kebutuhan fisiologis manusia (Muchlas, 2008:183). Sebagai kebutuhan dasar, makanan menjadi sangat penting bagi manusia sehingga dalam aspek bisnis pun makanan menjadi pilihan untuk dijadikan obyek bisnis. Tidak heran banyak individu yang tertarik dan menganggap bisnis kuliner sebagai jenis bisnis yang memiliki prospek yang baik, terbukti dari makin banyaknya rumah makan dan sentra kuliner di berbagai sudut kota. Selain sebagai kebutuhan dasar, kegiatan makan di luar rumah juga sudah menjadi gaya hidup masyarakat Indonesia, ditambah pula dengan meningkatnya daya beli serta pendapatan masyarakat.

Perilaku Konsumen merupakan hal yang kompleks, dimana tidak hanya unsur yang terlihat sebagai unsurnya, tetapi juga hal lainnya yang berhubungan dengan faktor pribadi dan psikologis. Hasil penelitian dari Rezka (2011) menunjukkan variabel harga, motivasi konsumen dan tempat yang diteliti terbukti secara positif dan signifikan mempengaruhi keputusan pembelian. Penelitian serupa juga dilakukan oleh Susanti (2012), Kurniawan (2013) yang menemukan bahwa variabel harga, lokasi dan kualitas pelayanan berpengaruh positif dan signifikan terhadap keputusan pembelian. 
Hal yang sama terjadi di kota Blitar Jawa Timur, di kota ini banyak perusahaan yang mengembangkan bisnis makanan dan semua bersaing demi merebut kepercayaan dari konsumen bahwa produk yang mereka tawarkan adalah yang terbaik yang dimulai dari skala kecil seperti warung-warung dan kafe tenda; bisnis makanan berskala menengah seperti depot, rumah makan dan cafe; sampai dengan bisnis makanan yang berskala besar seperti restoran-restoran di hotel berbintang.

Pecel adalah makanan khas masyarakat Jawa Timur. Meskipun selama ini pecel terkenal berasal dari kota Madiun, namun di daerah Jawa Timur yang lain tepatnya di kota Blitar, juga memiliki makanan khas berupa nasi pecel, yang tak kalah enak dengan nasi pecel yang berasal dari Madiun. Meskipun cara pembuatan maupun penyajiannya tak jauh berbeda, namun nasi pecel khas Blitar lebih terasa pedas dibanding pecel Madiun. Nasi Pecel Blitar memiliki karakteristik tingkat kepedasan yang cukup tinggi dan tekstur bumbu kacang yang masih sedikit kasar. Walaupun di kota Blitar telah berkembang restoran dan tempat-tempat makan, namun keberadaan warung-warung Pecel ini tetap menjadi tujuan kuliner warga Blitar. Jumlah Penjual nasi pecel di kota Blitar terbilang sangat banyak ini ditunjukkan dengan tabel 1.

\section{Tabel 1. Data Penjual Nasi Pecel di kota}

\section{Blitar Tahun 2013 - 2015}

\begin{tabular}{|c|c|c|}
\hline No & Tahun & Warung Pecel \\
\hline 1 & 2013 & 25 \\
\hline 2 & 2014 & 39 \\
\hline 3 & 2015 & 46 \\
\hline \multicolumn{2}{|c|}{ Sumber: BPS Kota Blitar } \\
\hline
\end{tabular}

Berdasarkan data yang ditampilkan dari BPS Kota Blitar dapat di lihat bahwa pertumbuhan Warung Pecel mengalami peningkatan dari tahun 2013 sampai tahun 2015 dari total jumlah warung pecel sebanyak 25 hingga 46 pada tahun 2015.

Dari jumlah warung pecel yang ada di kota Blitar ada beberapa warung pecel yang paling banyak jumlah konsumennya. Warung Pecel tersebut adalah Warung Pecel Mbok Bari, Warung Pecel Mak Ti dan Warung Pecel Moro Marem. Setiap Warung Pecel memiliki ciri khas yang berbeda-beda dari pelayanannya sampai fasilitas-fasilitas yang digunakan. Berikut ini adalah data jumlah konsumen dari Warung Pecel Mbok Bari, Warung Pecel Mak Ti dan Warung Pecel Moro Marem pada tahun 2015, pada tabel dipaparkan jumlah pembeli pada ketiga warung pecel tersebut pada bulan Januari sampai Desember 2015.

Berdasarkan data konsumen Rumah Warung Pecel Mbok Bari, Warung Pecel Mak Ti dan Warung Pecel Moro Marem pada bulan Januari sampai bulan Desember tahun 2015, menunjukkan terjadinya fluktuasi konsumen yang mengalami naik turun jumlah kunjungan tiap bulannya pada ketiga warung pecel tersebut ini disebabkan pesaing baru yang mencoba peruntungan di bisnis wisata kuliner di kota Blitar serta yang paling utama penyebab fluktuasi pengunjung disebabkan adanya liburan dan hari aktif dimana disaat liburan jumlah pengunjung bertambah dan ketika hari aktif.

Dalam kondisi semakin meningkatnya persaingan antara produk- produk sejenis, maka perusahaan yang satu dengan yang lain saling bersaing merebutkan konsumen. Perusahaan yang mampu menciptakan dan mempertahankan pelangganlah yang akan sukses dalam persaingan. Setiap perusahaan berusaha untuk memahami perilaku konsumen pada pasar sasaran untuk kelangsungan hidup perusahaan tersebut.

Pemilik warung-warung pecel di Blitar ini dituntut untuk dapat membaca keinginan dari pembelinya, sehingga dapat memberikan kepuasan kepada para pembelinya dan pembeli yang telah memutuskan untuk makan di warung tersebut tidak merasa kecewa. Dengan demikian, akan lebih mudah untuk bertahan dalam menghadapi persaingan bisnis yang ada, terutama bisnis kuliner di kota Blitar.

Rumah makan sebagai salah satu bisnis yang bergerak di bidang usaha makanan, diharapkan dapat menawarkan sesuatu yang unik dan dapat menjaring konsumen lebih banyak lagi. Hal tersebut dapat dilakukan dengan memberikan produk yang berkualitas bagi konsumen, sehingga konsumen dapat merasakan manfaat dari produk yang dibelinya. Kualitas produk merupakan salah satu variabel yang dapat mempengaruhi konsumen dalam melakukan keputusan pembelian. Menurut Wiyadi (2008) produk adalah sesuatu yang dapat memberikan kepuasan dan kebutuhan. Jika seorang pemasar dapat mengetahui dan mengindentifikasi kebutuhan konsumen, mengembangkan kualitas produk dengan baik, maka secara otomatis produknya akan laku di pasaran dan hal tersebut dapat meningkatkan laba atau profit bagi perusahaan.

Pelayanan yang dapat memuaskan konsumen akan berdampak terjadinya 
pembelian berulang-ulang yang berarti akan terjadi peningkatan penjualan. Dengan pelayanan yang baik dapat menciptakan kepuasan dan loyalitas konsumen serta membantu menjaga jarak dengan pesaing (Kotler, 1999:297).

Selain kualitas pelayanan, harga juga merupakan variabel penting dalam pemasaran. Harga yang rendah atau harga yang terjangkau menjadi pemicu untuk meningkatkan kinerja pemasaran (Ferdinand, 2002:11). Namun harga juga dapat menjadi indikator kualitas dimana suatu produk dengan kualitas tinggi akan berani dipatok dengan harga yang tinggi pula. Harga dapat mempengaruhi konsumen dalam mengambil keputusan untuk melakukan pembelian suatu produk.

Faktor lokasi juga merupakan faktor yang menentukan keberhasilan suatu bisnis. Menurut Jeni Raharjani (2005:5), strategi lokasi atau tempat adalah salah satu determinan yang paling penting dalam perilaku konsumen, perusahaan harus memilih lokasi yang stategis dalam menempatkan tokonya (Rumah Makan) di suatu kawasan atau daerah yang dekat dengan keramaian dan aktivitas masyarakat. Karena apabila terjadi kesalahan dalam memilih lokasi atau tempat akan berpengaruh besar pada kelangsungan hidup pemilik rumah makan.

Berdasarkan latar belakang diatas, peneliti tertarik melakukan kajian atau penelitian empiris mengenai "Analisis Pengaruh Kualitas Produk, Kualitas Pelayanan, Harga, dan Lokasi Terhadap Keputusan Pembelian Pada Warung-Warung Pecel di Kota Blitar".

\section{METODE PENELITIAN}

Jenis data digunakan pada penelitian ini kuantitatif. Menurut Sugiyono (2012: 23) "Data kuantitatif adalah data yang berbentuk angka". Penelitian ini menggunakan pendekatan kuantitatif dengan jenis penelitian asosiatif. Penelitian asosiatif adalah penelitian yang bersifat menanyakan hubungan antara dua variabel atau lebih. (Sugiyono,2011:36). Dalam penelitian ini, bentuk hubungan antara variabel yang diteliti adalah hubungan kausal. Hubungan kausal merupakan hubungan sebab akibat, dimana variabel $X$ yang berupa Kualitas Produk, Kualitas Pelayanan, Harga, dan Lokasi berpengaruh terhadap variabel $Y$ yang merupakan Keputusan Pembelian Pada Warung-Warung Peceldi Kota Blitar.

Populasi dalam penelitian ini adalah seluruh konsumen warung-warung pecel di Blitar yang sudah pernah atau sudah beberapa kali makan di warung makan-warung pecel tersebut. Teknik pengambilan sampel yang digunakan dalam penelitian ini adalah pruposive sampling. Pengambilan sampel di lokasi penelitian yaitu terhadap konsumen pada ketiga warung-warung pecel di Blitar.

Penentuan jumlah sampel karena besar populasi tidak diketahui sehingga didasarkan pada pendapat dari Roscoe (1982:253) dalam Sugiyono (2015:131) yang memberikan pedoman penentuan jumlah sampel sebagai berikut:

1. Ukuran Sampel yang layak dalam penelitian adalah antara 30 sampai dengan 500.

2. Bila dalam penelitian akan melakukan analisis dengan multivariate (korelasi atau regresi ganda misalnya), maka jumlah anggota minimal 10 kali dari jumlah variabel yang diteliti. Misalnya variabel penelitiannya ada 5 (independen + dependen), maka jumlah anggota sampel = $10 \times 5=50$

Berdasarkan pendapat di atas, yaitu ukuran sampel sebaiknya antara 30 hingga 500 elemen maka dalam penelitian ini, peneliti hanya membatasi sebanyak 100 responden (konsumen).

Analisis regresi berganda digunakan untuk memeriksa kuatnya hubungan antara variabel bebas dengan variabel terikat. Maka dalam penelitian ini regresinya sebagai berikut (Sugiyono, 2005: 250).

$$
\begin{aligned}
& Y=a+b_{1} X_{1}+b_{2} X_{2}+b_{3} X_{3}+b_{4} X_{4}+e \\
& \text { Keterangan : } \\
& \text { Y : Keputusan pembelian } \\
& b_{1} \quad \text { : Koefisien regresi kualitas } \\
& \text { produk } \\
& b_{2} \quad \text { : Koefisien regresi kualitas } \\
& \text { pelayanan } \\
& b_{3} \quad \text { : Koefisien regresi harga } \\
& \mathrm{b}_{4} \quad \text { :Koefisien regresi lokasi } \\
& \mathrm{X}_{1} \quad \text { : Kualitas Produk } \\
& \mathrm{X}_{2} \quad \text { : Kualitas Pelayanan } \\
& X_{3} \quad \text { : Harga } \\
& \mathrm{X}_{4} \quad \text { : Lokasi } \\
& \text { a : Konstanta } \\
& \text { e : variabel di luar model } \\
& \text { (standart error) }
\end{aligned}
$$
mengetahui apakah secara simultan koefisien variabel bebas mempunyai pengaruh nyata atau tidak terhadap variabel terikat, (Ferdinand, 2006),

Uji t (Uji Parsial) digunakan untuk mengetahui pengaruh dari variabel kualitas produk, kualitas pelayanan, harga dan lokasi terhadap keputusan pembelian pada warungwarung pecel di Blitar maka akan digunakan uji t yang akan dihitung melalui SPSS. 


\section{HASIL PENELITIAN}

\section{A. Deskripsi Variabel Penelitian}

Kualitas produk adalah Jaminan mutu yang diberikan kepada konsumen, baik dari variasi menu dan kebersihan yang terjamin,sehingga konsumen merasa aman untuk mengkonsumsi produk pecel di Warung Pecel Mbok Bari, Warung Pecel Mak Ti dan Warung Pecel Moro Marem. Rata-rata total dari Kualitas Produk dari tanggapan responden sebesar 3,36 dengan kriteria Cukup Baik. Kriteria ini menunjukkan bahwa Konsumen Warung-Warung Pecel di Blitar memiliki Kualitas Produk yang Cukup Baik.

Kualitas Pelayanan mencerminkan perbandingan antara tingkat layanan yang disampaikan perusahaan dibandingkan ekspetasi pelanggan. Rata-rata total dari Kualitas pelayanan dari tanggapan responden sebesar 2,93 dengan kriteria cukup Baik. Kriteria ini menunjukkan bahwa WarungWarung Pecel di Blitar memberikan pelayanan yang cukup Baik.

Harga merupakan jumlah nilai yang dipertukarkan konsumen untuk manfaat memiliki atau menggunakan produk atau jasa (Kotler, 2006,p.249). Rata-rata total dari kategori Harga dari tanggapan responden sebesar 2,84 dengan kriteria Cukup Sesuai. Kriteria ini menunjukkan bahwa WarungWarung Pecel di Blitar cukup Sesuai dalam menentukan harga produk.

Lokasi berhubungan dengan letaknya usaha dan akses transportasi yang memudahkan serta kenyamanan dan keamanan tempat yang diberikan.Rata-rata total dari Lokasi dari tanggapan responden sebesar 3,30 dengan kriteria Cukup Nyaman. Kriteria ini menunjukkan bahwa WarungWarung Pecel di Blitar memiliki lokasi yang Cukup Nyaman.

Keputusan pembelian adalah perilaku konsumen dalam mengambil keputusan untuk membeli produk karena keinginan mencoba produk tersebut dan keputusan untuk melakukan pembelian ulang. Rata-rata total dari Keputusan Pembelian berdasarkan tanggapan responden sebesar 4,11 dengan kriteria tinggi. Kriteria ini menunjukkan bahwa Konsumen Warung-Warung Pecel di Blitar memiliki Keputusan Pembelian yang tinggi.

\section{HASIL ANALISIS REGRESI LINER BERGANDA}

Analisis regresi berganda digunakan untuk mengetahui pengaruh Kualitas Produk, Kualitas Pelayanan, Harga, dan Lokasi terhadap Keputusan Pembelian Konsumen Warung-Warung Pecel di Blitar. Untuk melihat bagaimana fungsi regresi yang dapat dirumuskan dari hasil perhitungan dengan SPSS maka dapat dilihat pada tabel 2., di bawah ini.

Tabel 2. Signifikansi Parameter

\begin{tabular}{|l|c|c|}
\hline \multirow{2}{*}{ Model } & \multicolumn{2}{c|}{$\begin{array}{c}\text { Unstandardized } \\
\text { Coefficients }\end{array}$} \\
\cline { 2 - 3 } & $\mathrm{B}$ & $\begin{array}{c}\text { Std. } \\
\text { Error }\end{array}$ \\
\hline 1 (Constant) & 1,092 & 0,261 \\
Kualitas Produk & 0,255 & 0,063 \\
Kualitas Pelayanan & 0.208 & 0,070 \\
Harga & 0,226 & 0,074 \\
Lokasi & 0,114 & 0,035 \\
\hline \multicolumn{2}{|c}{} \\
\hline
\end{tabular}

a Dependent Variable: Keputusan

Pembelian

Sumber : Data diolah

Melalui tabel 1., di atas maka dapat dirumuskan fungsi dari regresi linier sebagai berikut :

$$
\mathrm{Y}=1,092+0,255 \mathrm{X}_{1+}
$$

$0,208 X_{2}+0,226 X_{3}+0,114 X_{4}$

Keterangan :

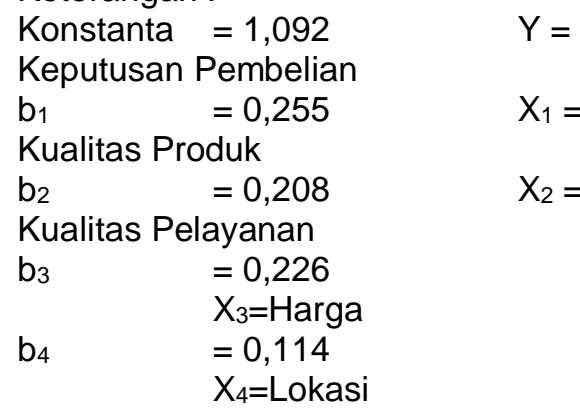

Fungsi linier tersebut di atas dapat dijabarkan sebagai berikut. Nilai konstanta sebesar 1,092 berarti bahwa apabila masingmasing variabel independen memiliki nilai 0 , maka Keputusan Pembelian Konsumen Warung-Warung Pecel di Blitar bernilai positif sebesar 1,092. Hal ini bermakna bahwa Keputusan Pembelian tetap bernilai positif (tetap memiliki Keputusan Pembelian) ketika tidak adanya Kualitas Produk, Kualitas Pelayanan, Harga, dan Lokasi.

Koefisien regresi dari Kualitas Produk (b1) yang bernilai sebesar 0,255 berarti bahwa apabila variabel Kualitas Produk $\left(X_{1}\right)$ ditingkatkan maka Keputusan Pembelian akan mengalami kenaikan sebesar 0,255. Koefisien regresi Kualitas Produk $\left(b_{1}\right)$ yang bernilai positif ini bermakna bahwa semakin tinggi Kualitas Produk maka Keputusan Pembelian Konsumen tersebut akan semakin tinggi. Begitu pula sebaliknya semakin rendah 
Kualitas Produk maka Keputusan Pembelian Konsumen semakin rendah.

Koefisien regresi dari Kualitas Pelayanan $\left(b_{2}\right)$ yang bernilai 0,208 menjelaskan bahwa apabila variabel Kualitas Pelayanan $\left(\mathrm{X}_{2}\right)$ ditingkatkan maka Keputusan Pembelian mengalami peningkatan sebesar 0,208 . Koefisien regresi Kualitas Pelayanan $\left(\mathrm{b}_{2}\right)$ yang bernilai positif ini bermakna bahwa semakin baik Kualitas Pelayanan, maka Keputusan Pembelian Konsumen tersebut akan semakin kuat. Begitu pula sebaliknya, semakin rendah Kualitas Pelayanan maka Keputusan Pembelian tersebut akan semakin rendah.

Koefisien regresi dari Harga $\left(b_{3}\right)$ yang bernilai 0,226 menjelaskan bahwa apabila variabel Kualitas Pelayanan $\left(X_{3}\right)$ ditingkatkan maka Keputusan Pembelian mengalami peningkatan sebesar 0,226 . Koefisien regresi Harga $\left(b_{3}\right)$ yang bernilai positif ini bermakna bahwa semakin baik Harga yang ditetapkan, maka Keputusan Pembelian tersebut akan semakin kuat. Begitu pula sebaliknya, semakin rendah Harga yang ditetapkan maka Keputusan Pembelian tersebut akan semakin rendah.

Koefisien regresi dari Lokasi $\left(b_{4}\right)$ yang bernilai 0,114 menjelaskan bahwa apabila variabel Lokasi $\left(X_{4}\right)$ ditingkatkan maka Keputusan Pembelian mengalami peningkatan sebesar 0,114 . Koefisien regresi Lokasi $\left(b_{4}\right)$ yang bernilai positif ini bermakna bahwa semakin baik Lokasi usaha, maka Keputusan Pembelian tersebut akan semakin tinggi. Begitu pula sebaliknya, semakin rendah Lokasi maka Keputusan Pembelian tersebut akan semakin rendah.

\section{A. Hasil Analisis Goodness Of Fit (Uji F)}

Uji Kelayakan Model (Goodness Of Fit) Uji $F$ jika hasilnya signifikan maka uji ini dapat digunakan untuk memprediksi model. Untuk melihat bagaimana kelayakan pengaruh dari kualitas produk, kualitas pelayanan, harga dan lokasi berpengaruh terhadap keputusan pembelian pada warung-warung pecel di Blitar digunakan uji F.

Berikut disajikan tabel 3., hasil perhitungan uji $\mathrm{F}$ dengan SPSS.

Tabel 3. Hasil Uji F variabel bebas terhadap variabel terikat

\begin{tabular}{|ll|r|r|r|r|c|}
\hline Model & & $\begin{array}{c}\text { Sum of } \\
\text { Squares }\end{array}$ & df & Mean Square & F & Sig. \\
\hline 1 & Regression & 3,267 & 4 &, 817 & 34,369 &, $000^{\mathrm{a}}$ \\
& Residual & 2,258 & 95 &, 024 & & \\
\hline & \multicolumn{7}{|c|}{ Total } & 5,525 & 99 & & & \\
\hline
\end{tabular}

\section{Sumber : Data diolah}

Berdasarkan tabel 3., di atas diperoleh nilai $\mathrm{F}$ hitung sebesar 34,369. Kemudian, dengan menggunakan tingkat keyakinan $95 \%$, $a=5 \%$, df 1 (jumlah variabel -1$)=5-1=4$, dan df2 $(n-k)=100-5=95$, sehingga diperoleh hasil untuk $F$ tabel sebesar 2,467. Sehingga oleh karena $\mathrm{F}$ hitung $>\mathrm{F}$ tabel $(34,369>2,467)$ maka dapat disimpulkan bahwa hasil uji goodness of fit (uji kelayakan) dari model regresi adalah signifikan. Hasil ini menunjukkan bahwa model regresi yang dihasilkan dalam penelitian ini adalah layak digunakan sebagai prediksi.

Sehingga dapat disimpulkan bahwa hipotesa kedua $\left(\mathrm{H}_{2}\right)$ yang menyatakan bahwa "terdapat pengaruh yang signifikan secara simultan dari Kualitas Produk, Kualitas Pelayanan, Harga dan Lokasi terhadap Keputusan Pembelian Konsumen WarungWarung Pecel di Blitar" dapat diterima.

\section{B. Analisis Uji Signifikansi Parsial (Uji T)}

Untuk melihat bagaimana pengaruh secara parsial dari Kualitas Produk, Kualitas Pelayanan, Harga, dan Lokasi terhadap Keputusan Pembelian Konsumen WarungWarung Pecel di Blitar digunakan uji t.

Tabel 4. Hasil Uji t variabel bebas terhadap variabel terikat

\begin{tabular}{|c|c|c|c|c|c|c|}
\hline \multirow[b]{2}{*}{ Mode } & & \multicolumn{2}{|c|}{$\begin{array}{c}\text { Unstandardized } \\
\text { Coefficients }\end{array}$} & \multirow{2}{*}{$\begin{array}{c}\begin{array}{c}\text { Standardized } \\
\text { Coefficients }\end{array} \\
\text { Beta }\end{array}$} & \multirow[b]{2}{*}{$t$} & \multirow[b]{2}{*}{ Sig. } \\
\hline & & $B$ & Std. Error & & & \\
\hline \multirow[t]{5}{*}{1} & $\begin{array}{l}\text { (Constant) } \\
\end{array}$ & 1,092 & 261 & & 4,175 & 0,000 \\
\hline & Kualitas Produk & ,255 & ,063 & ,326 & 4,047 & ,000 \\
\hline & Kualitas Pelayanan & ,208 & ,070 & ,235 & 2,983 & ,004 \\
\hline & Harga & ,226 & ,074 & ,253 & 3,065 & ,003 \\
\hline & Lokasi & 114 & ,035 & ,225 & 3,232 & ,002 \\
\hline
\end{tabular}

Sumber : Data diolah

Dengan menggunakan tingkat keyakinan $95 \%$ dimana $a=5 \%$, df (degree fredom) $\mathrm{n}-1=100-1=99$, sehingga diperoleh hasil untuk $t$ tabel sebesar 1,984. Sehingga karena $\mathrm{t}$ hitung Kualitas Produk $>\mathrm{t}$ tabel 4,047>1,984), $t$ hitung Kualitas Pelayanan $>t$ tabel $(2,983>1,984)$, $t$ hitung Harga $>t$ tabel $(3,065>1,984)$, $t$ hitung Lokasi $>t$ tabel $(3,232>1,984)$ maka dapat disimpulkan bahwa terdapat pengaruh yang signifikan secara parsial dari Kualitas Produk, Kualitas Pelayanan, Harga, Lokasi terhadap Keputusan Pembelian pada Warung-Warung Pecel di Blitar. Sehingga dapat disimpulkan bahwa hipotesa pertama $\left(\mathrm{H}_{1}\right)$ yang menyatakan bahwa "ada pengaruh yang signifikan antara Kualitas Produk, Kualitas Pelayanan, Harga dan Lokasi secara parsial terhadap Keputusan Pembelian pada warung-warung pecel di Blitar" dapat diterima.

\section{Analisis Koefisien Determinasi Parsial}

Koefisien determinasi parsial digunakan untuk mengetahui variabel yang paling dominan mempengaruhi variabel dependen. Koefisien determinasi/korelasi dapat dilihat pada tabel berikut.

Tabel 5. Hasil Uji Korelasi Parsial 


\begin{tabular}{|l|c|}
\hline \multicolumn{1}{|c|}{ Model } & $\begin{array}{c}\text { Standardized Coeficient } \\
\text { Beta }\end{array}$ \\
\hline Kualitas Produk & 0,326 \\
\hline Kualitas Pelayanan & 0,235 \\
\hline Harga & 0,253 \\
\hline Lokasi & 0,225 \\
\hline
\end{tabular}

a Dependent Variable: Keputusan Pembelian Sumber : Data diolah

Berdasarkan tabel di atas, pengaruh yang sudah terstandarisasi untuk Kualitas Produk dengan Keputusan Pembelian sebesar adalah 0,326, Kualitas Pelayanan dengan Keputusan Pembelian sebesar 0,235, Harga dengan Keputusan Pembelian sebesar 0,253, Lokasi dengan Keputusan Pembelian sebesar 0,225. Hal ini menunjukkan bahwa Kualitas Produk memiliki pengaruh yang paling dominan terhadap Keputusan Pembelian. Sehingga dapat disimpulkan bahwa hipotesa ketiga $\left(\mathrm{H}_{3}\right)$ yang menyatakan bahwa "Kualitas Produk memiliki pengaruh yang paling dominan terhadap Keputusan Pembelian pada warung-warung pecel di Blitar" dapat diterima.

\section{PEMBAHASAN \\ A.Pengaruh Kualitas Produk Terhadap Keputusan Pembelian}

Berdasarkan hasil analisis data dapat diketahui bahwa kualitas produk secara parsial berpengaruh terhadap keputusan pembelian. Kualitas produk yang dilihat dari indikator porsinya pas, kualitas rasa yang unggul dan kebersihan terjamin sesuai dengan harapan konsumen, karena salah satunya rasa pecelnya yang menggugah selera konsumen. Apabila kualitas produk dari warung-warung pecel dapat memuaskan keinginan konsumen maka konsumen akan memberikan penilaian yang baik terhadap produk tersebut. Hasil ini memperkuat penelitian yang dilakukan oleh Kurniawan (2013) menemukan kualitas produk berpengaruh positif dan signifikan terhadap keputusan pembelian; Ghanimata (2012) menemukan kualitas produk berpengaruh positif dan signifikan terhadap keputusan pembelian; Antyadika (2012) menemukan kualitas produk berpengaruh positif dan signifikan terhadap keputusan pembelian; Kurniawan(2013) menemukan kualitas produk berpengaruh positif dan signifikan terhadap keputusan pembelian; Santoso (2014) menemukan kualitas produk berpengaruh positif dan signifikan terhadap keputusan pembelian. Penelitian ini sesuai dengan pendapat Kotler dan Amstrong (2010:27) yang menyatakan kualitas produk adalah kemampuan suatu produk untuk melaksanakan fungsinya, meliputi kehandalan, daya tahan, ketepatan, kemudahan operasi, dan perbaikan produk, serta atribut bernilai lainnya. Dapat disimpulkan bahwa kualitas produk berpengaruh positif dan signifikan terhadap keputusan pembelian.

\section{B.Pengaruh Kualitas Pelayanan Terhadap Keputusan Pembelian}

Berdasarkan hasil analisis data dapat diketahui bahwa kualitas pelayanan secara parsial berpengaruh terhadap keputusan pembelian. Kualitas layanan yang dilihat dari indikator pelayanan yang cepat, kualitas yang dapat diandalkan, dan daya tanggap karyawan. Konsumen merasa nyaman dengan layanan yang diberikan oleh para karyawan warung pecel serta nuansa warung pecel yang nyaman dimana dilengkapi dengan toilet, TV dan music. Hasil ini memperkuat penelitian yang dilakukan oleh Kurniawan (2013) menemukan bahwa kualitas pelayanan berpengaruh positif dan signifikan terhadap keputusan pembelian; Marlina (2015) menemukan bahwa Kualitas Pelayanan berpengaruh positif terhadap keputusan pembelian. Hasil penelitian ini sesuai dengan pendapat Tjiptono (2008:59) yang menyatakan bahwa kualitas layanan adalah tingkat keunggulan yang diharapkan dan pengendalian atas tingkat keunggulan tersebut untuk memenuhi keinginan pelanggan. Dapat disimpulkan bahwa kualitas pelayanan berpengaruh positif dan signifikan terhadap keputusan pembelian.

\section{C.Pengaruh Harga Terhadap Keputusan Pembelian}

Berdasarkan hasil analisis data dapat diketahui bahwa harga secara parsial berpengaruh terhadap keputusan pembelian. Harga yang dilihat berdasarkan indikator adalah harga terjangkau, harga yang sesuai dengan rasa dan daya saing harga yang ditetapkan Warung-warung Pecel sesuai dengan harapan konsumen, karena harganya sesuai dengan kualitas produk, dan daya saing harga yang ditetapkan. Dengan harga mulai dari Rp.4000,-an sampai dengan Rp12,000-an konsumen sudah mampu menikmati nasi pecel dan pilihan lauk. Hal ini menunjukkan bahwa harga yang ditetapkan Warung-warung pecel terjangkau bagi konsumen dari berbagai kalangan serta memiliki harga yang bersaing. Hasil ini memperkuat penelitian yang dilakukan oleh Rezka (2011) menemukan bahwa harga terbukti secara positif dan signifikan mempengaruhi keputusan pembelian; Ghanimata (2012) harga terbukti secara positif dan signifikan mempengaruhi keputusan pembelian; Antydika(2012) menemukan 
bahwa harga terbukti secara positif dan signifikan mempengaruhi keputusan pembelian; Kurniawan (2013) menemukan bahwa harga terbukti secara positif dan signifikan mempengaruhi keputusanpembelian; Marlina (2015) menemukan bahwa harga terbukti secara positif dan signifikan mempengaruhi keputusan pembelian. Hasil penelitian ini sesuai dengan Husain Umar (2000) bahwa harga adalah "sejumlah nilai yang ditukarkan konsumen dengan manfaat dari memiliki atau menggunakan produk atau jasa yang nilainya ditetapkan oleh pembeli dan penjual melalui tawar menawar, atau ditetapkan oleh penjual untuk satu harga yang sama terhadap semua pembeli".

\section{D.Pengaruh Lokasi Terhadap Keputusan Pembelian}

Berdasarkan hasil analisis data dapat diketahui bahwa lokasi secara parsial berpengaruh terhadap keputusan pembelian. Lokasi yang dilihat dari indikator mudah dijangkau, parker yang luas dan aman serta lingkungan yang mendukung. Lokasi warungwarung pecel berdekatan dengan sekolahsekolah serta pusat perbelanjaan dan tempat wisata. Selain itu, warung-warung pecel juga dekat dengan pemukiman warga serta terminal sehingga lokasi ini ramai dan mudah diakses.Berdasarkan hasil analisis menunjukkan warung-warung pecel mudah dijangkau oleh para konsumen, karena aksesnya yang banyak dilalui transportasi serta mudah dijangkau oleh berbagai jenis transportasi. Hasil ini memperkuat penelitian yang dilakukan oleh Ghanimata (2012) menemukan bahwa lokasi berpengaruh positif dan signifikan terhadap keputusan pembelian; Antyadika (2012) menemukan bahwa lokasi berpengaruh positif dan signifikan terhadap keputusan pembelian; Kurniawan (2013) menemukan bahwa lokasi berpengaruh positif dan signifikan terhadap keputusan pembelian; Santoso (2014) menemukan bahwa lokasi berpengaruh positif dan signifikan terhadap keputusan pembelian. Penelitian ini sesuai dengan pendapat Lupiyoadi (2001:80) lokasi merupakan keputusan yang dibuat perusahaan berkaitan dengan dimana operasi dan stafnya akan ditempatkan. Dapat disimpulkan bahwa lokasi berpengaruh positif dan signifikan terhadap keputusan pembelian.

\section{E.Pengaruh kualitas produk, kualitas layanan, harga, dan lokasi secara simultan terhadap keputusan pembelian}

Berdasarkan hasil analisis data

dapat diketahui bahwa kualitas produk, kualitas layanan, harga, dan lokasi secara simultan terhadap keputusan pembelian. Konsumen menilai bahwa kualitas produk Warung-warung pecel sesuai yang diharapkan. Mulai dari porsinya yang pas, kualitas rasa yang unggul dan kebersihan terjamin. Adanya berbagai pilihan lauk yang mampu menjangkau selera konsumen. Sehingga membuat cita rasa yang lezat serta unik di lidah sehingga mampu sesuai dengan harapan konsumen. Selain itu harga makanan yang diterapkan Warung-warung Pecel terjangkau bagi konsumen. Adanya pilihan harga juga mampu menjangkau konsumen dari berbagai kalangan. Harga yang ditawarkan pun sesuai dengan harapan konsumen baik dari segi rasa yang lezat maupun penyajian yang menarik. Hasil penelitian ini juga menujukkan bahwa ada pengaruh lokasi. Warung-warung pecel mudah ditemukan konsumen karena memiliki papan nama yang jelas, lokasi Warung-warung pecel mudah dijangkau oleh konsumen baik transportasi umum maupun kendaraan pribadi, selain itu lokasi dekat dengan pemukiman penduduk, sekolah, tempat wisata serta pusat perbelanjaan.

Konsumen merasa nyaman dengan adanya alunan musik, dan menonton tayangan televisi. Keandalan serta ketanggapan dari para pegawai Warungwarung pecel yang baik sehingga membuat konsumen tidak perlu menunggu lama dalam menunggu sajian. Hal ini mendukung penelitian dari Kurniawan (2013) yang menyatakan bahwa kualitas produk, kualitas layanan harga, dan lokasi mempengaruhi keputusan pembelian konsumen.

\section{F.Dominasi Kualitas Produk terhadap Keputusan Pembelian}

Hasil analisis data menghasilkan kesimpulan penelitian bahwa kualitas produk berpengaruh dominan terhadap Keputusan Pembelian. Temuan ini juga diperkuat oleh hasil penelitian dari Marlina (2015) menemukan bahwa kualitas produk memiliki pengaruh yang paling dominan terhadap keputusan pembelian. Kualitas produk merupakan fokus utama dalam perusahaan. Untuk produk yang merupakan kebutuhan pokok seperti makanan dan minuman, konsumen sangat mempertimbangkan kualitasnya (Tedjakusuma, Hartini, dan Muryani, 2001). Karena sangat berhubungan dengan kesehatan manusia dan merupakan kebutuhan pokok, maka kualitas produk sangat mempengaruhi pembeli dalam mengambil keputusan pembelian.

\section{KESIMPULAN}


Dari hasil penelitian dan pembahasan di atas, maka kesimpulan dari penelitian yang dapat diambil adalah :

1. Kualitas Produk berpengaruh positif dan signifikan terhadap Keputusan Pembelian Konsumen pada WarungWarung Pecel di Blitar. Ini dikarenakan semakin baik kualitas produk yang diberikan, maka semakin tinggi keputusan pembelian.

2. Kualitas Pelayanan berpengaruh positif dan signifikan terhadap Keputusan Pembelian Konsumen pada WarungWarung Pecel di Blitar. Hasil dari penelitian ini membuktikan bahwa kualitas pelayanan yang baik mampu mengarahkan dan pada akhirnya akan mendorong terbentuknya keputusan pembelian. Hal ini menunjukkan bahwa performa dalam penyajian layanan jasa yang baik sangat diperhatikan oleh konsumen, baik itu dari penampilan para karyawan, daya tanggap karyawan menjadi nilai tersendiri bagi konsumen, konsumen puas dengan apa yang ia dapatkan, kemungkinan untuk menggunakan jasa yang sama lebih besar bahkan akan merekomendasikan ke orang lain dan secara tidak langsung berpengaruh terhadap keputusan pembelian.

3. Harga berpengaruh positif dan signifikan terhadap Keputusan Pembelian Konsumen pada Warung-Warung Pecel di Blitar. Hasil dari penelitian ini membuktikan bahwa harga yang kompetitif pada akhirnya akan mendorong terbentuknya keputusan pembelian.

4. Lokasi berpengaruh positif dan signifikan terhadap Keputusan Pembelian Konsumen pada WarungWarung Pecel di Blitar. Hasil dari penelitian ini membuktikan bahwa lokasi yang strategis berpengaruh terhadap keputusan pembelian.

5. Secara simultan variabel Kualitas Produk, Kualitas Pelayanan, Harga, dan Lokasi berpengaruh signifikan terhadap Keputusan Pembelian Konsumen pada Warung-Warung Pecel di Blitar. Artinya, setiap perubahan yang terjadi pada variabel independen yaitu Kualitas Produk, Kualitas Pelayanan, Harga, dan Lokasi secara simultan atau bersamasama akan berpengaruh pada Keputusan Pembelian Konsumen pada Warung-Warung Pecel di Blitar. Ini dikarenakan hasil penelitian menunjukkan pengaruh Kualitas Produk,
Kualitas Pelayanan, Harga, dan Lokasi terhadap Keputusan Pembelian sebesar $59,1 \%$.

6. Variabel yang mempunyai pengaruh paling dominan terhadap Keputusan Pembelian Konsumen pada WarungWarung Pecel di Blitar adalah Kualitas Produk. Hasil ini mencerminkan semakin baik kualitas produk yang dimiliki oleh Warung-warung pecel maka akan semakin meningkatkan Keputusan Pembelian. Kualitas produk yang baik berdampak pada Keputusan Pembelian.

\section{DAFTAR PUSTAKA}

Ardhana, Oldy. 2010. "Analisis Pengaruh Kualitas Pelayanan, Harga, dan Lokasi Terhadap Kepuasan Pelanggan (Studi pada Bengkel Caesar Semarang)". Skripsi. Semarang: Fakultas Ekonomika dan Bisnis, Universitas Diponegoro.

Alma, Buchari. 2002. Manajemen Pemasaran dan Pemasaran Jasa. Edisi Revisi. Cetakan kelima. CV Alfabet. Bandung

Angipora, Marius. 2002. Dasar-Dasar Pemasaran. Edisi Kedua. PT Raja Grafindo Persada. Jakarta.

Antyadika, Bonaventura Efrian . 2012. "Analisis Pengaruh Lokasi, Harga, Dan Kualitas Produk Terhadap Keputusan Pembelian (Studi pada Wong Art Bakery \& Café Semarang)". Skripsi. Semarang: Fakultas Ekonomika dan Bisnis, Universitas Diponegoro.

Augusty Ferdinand. 2006. Metode Penelitian Manajemen : Pedoman Penelitian untuk Penulisan Skripsi, Tesis, dan Disertasi IImu Manajemen. Semarang : Badan Penerbit Universitas Diponegoro

Hermawan Kartajaya. 2006. Hermawan Kartajaya on Positioning. Bandung: Mizan.

Dyah Ayu Pradipta. 2012. Pengaruh Citra Merek Brand Image Terhadap Loyalitas Konsumen Produk Oli Pelumas PT Pertamina (PERSERO). Enduro $4 T$ di Makassar.Skripsi, Ekonomi-S1, Fakultas Ekonomi, Universitas Hasanuddin, Makassar. 
Djarwanto, Ps dan Pangestu Subagyo. 1993. Statistik Induktif. Edisi Empat. BPFE. Yogyakarta

Kurniawan,Tommy.2013. Analisis Pengaruh Kualitas Produk, Kualitas Layanan Dan Lokasi Terhadap Keputusan Pembelian Motor Matic Di Raharjo Motor, Jepara. Diponegoro Journal Of Management.Tersedia di http://ejournals1.undip.ac.id/index.php/dbr. Volume 2, Nomor 3, Tahun 2013, Halaman 49 ISSN : 2337-3792

Kotler, Philip. 2005. Manajemen Pemasaran. Edisi XI. Jakarta : Indeks

Lupiyoadi, Rambat. 2001. Manajemen Pemasaran Jasa. Edisi XI. Jakarta : Salemba Empat

Martanti, Anastasia Dwi Febri. 2006. Analisis Strategi Differensiasi, Promosi, dan Kualitas Layanan Dalam Meningkatkan Minat Beli. SKRIPSI

Munfaat, Imron. 2003. Membangun Keunggulan Produk. JURNAL SAINS PEMASARAN INDONESIA. Vol. II, No. 3, 219-232

Muchlas, Makmuri. 2008. Perilaku Organisasi. Gadjah Mada University Press. Yogyakarta

Marlina,Yeni.2015. Pengaruh Produk, Harga Dan Kualitas Layanan Terhadap Keputusan Pembelian Pada Rumah Makan Sederhana By Pass Padang.Skripsi Universitas Taman Siswa Malang

M,Novian Rezka.2011. Analisis Pengaruh Harga, Motivasi Konsumen, Dan Tempat Terhadap Keputusan Pembelian(Studi Pada Pengunjung Pujasera "Jaya Makmur" Di Semarang).Skripsi Universitas Diponegoro Semarang

$\begin{array}{ccr}\text { Nanang } \quad \text { Tasunar. } & 2006 . & \text { "Kualitas } \\ \text { Layanan } & \text { Sebagai } & \text { Strategi } \\ \text { Menciptakan } & \text { Kepuasan } & \text { pada }\end{array}$

Pangkalan Pendaratan Ikan (PPI) Morodemak". Jurnal Sains Pemasaran Indonesia, Vol. V No. 1 Mei 2006, hal. 41-62.

Niti Semito, Alex S. 1991. Marketing. Jakarta. Ghalia. Indonesia

Nurgiyantoro, Burhan, Gunawan dan Marzuki. 2004. Statistik Terapan : Untuk Penelitian IImu-IImu Sosial. Cetakan Ketiga (Revisi). Gadjah Mada University Press. Yogyakarta

Raharjani, Jeni. 2005. Analisis Faktor yang Mempengaruhi Keputusan Pemilihan Pasar Swalayan Sebagai Tempat Berbelanja. Jurnal Studi Manajemen dan Organisasi, Vol. 2, No. 1

Santoso, Singgih. 2004. SPSS Versi 10 Mengolah Data Statistik Secara Profesional. Jakarta: PT. Gramedia

Santoso ,Tri Adhi. 2014. Analisis Pengaruh Harga, Lokasi Dan Kualitas Produk Terhadap Keputusan Pembelian (Studi Pada Warung Makan Geole Semarang). Skripsi Fakultas Ekonomika dan Bisnis Universitas Diponegoro.

Tjiptono, Fandy.2001, Strategi Pemasaran, edisi kedua,Yogyakarta: Penerbit Andi

Uma Sekaran, 2006, Metodologi Penelitian untuk Bisnis, Edisi 4, Buku 2, Jakarta: Salemba Empat.

Wahyudi, Lilik. 2004. Peran Harga Sebagai Indikator Kualitas Jasa Persepsi dan Pengaruh Terhadap Kemungkinan Menmbeli Konsumen. Fokus Manajerial, Vol. 2, No. 2, 101-120

Wisnalmawati. 2005. Pengaruh Persepsi Dimensi Kualitas Layanan Terhadap Niat pembelian Ulang. Jurnal Ekonomi dan Bisnis, No. 3 Jilid 10 2005, hal.153165. 